J. Clin. Chem. Clin. Biochem.

Vol. 16, 1978, pp. $5.61-565$

\title{
Investigation of Reference Values of Components of Cerebrospinal Fluid
}

By K. Breebaart,

Department of Clinical Chemistry,

\author{
H. Becker, and F. A. Jongebloed
}

Department of Neurology Hervormd Diaconnessenhuis, Arnhem, The Netherlands

(Received December 5, 1977/June 2, 1978)

\begin{abstract}
Summary: In order to obtain reference values, random samples of CSF from 70 women and 69 men were analyzed for various components, including total protein and protein fractions. Using statistical methods, data were also collected for sex differences and the influence of age.
\end{abstract}

Small variations in the values of total protein, albumin and $\gamma$-globulin between males and females were found, and slightly higher values for the $\gamma$-globulin were found with increasing age.

\section{Untersuchung der Normalwerte von Komponenten im Liquor cerebrospinalis}

Zusammenfassung: Zur Gewinnung von Normalwerten wurden an einer Stichprobe von 70 Frauen und 69 Männer verschiedene Komponenten im Liquor cerebrospinalis analy siert. Die Normalwerte wurden nach statistischen Methoden bestimmt. Nur eine geringe Geschlechtsabhängigkeit für Gesamt-Eiweiß, Albumin und $\gamma$-Globuline wurde gefunden. Nur für die $\gamma$-Globuline konnte eine Altersabhängigkeit festgestellt werden.

\section{Introduction}

There is a continuing discussion in the literature over reference values for cerebrospinal fluid (CSF) components, differences between the sexes and the influence of age (1-4).

Reference values are dependent on the methods used and differencès will always be found.

Furthermore evaluation of normal CSF samples must be retrospective and it takes many years to collect sufficient samples for statistical evaluation.

In the period 1969-1975, 139 "normals" were selected from a group of nearly 1000 patients.

Statistical examination was carried out in cooperation with the Computing Centre of the University of Nijmegen (URC). In this statistical evaluation tests were done for normality or log normality of the variables, using the test of d'Agostino. Comparisons were made between the various distributions. The influence of age was investigated by comparing the group $20-40$ years of age and the group $>40$ years.
These groups contain 50 and 55 persons respectively. Differences between the sexes were estimated using the same statistical methods.

The "normals" were selected on the basis of:

1. Normal neurological examinations and no other known diseases.

2. Additional examination: $X$-ray, electroencephalography (E.E.G.), electromyography (E.M.G.), electronystagmography (E.N.G.), echoencephalography, airencephalography (A.E.G.), arteriography.

3. Lumbar puncture: no cells in the CSF sample. The normal group consisted of 139 persons of whom 69 were male and 70 female. The average age was 38 years and the frequency distribution was almost Gaussian (fig. 1).

The CSF samples were obtained by lumbar puncture and were analysed for glucose, chloride, lactate dehydrogenase, aspartate transaminase, total protein and protein composition by protein electrophoresis. 


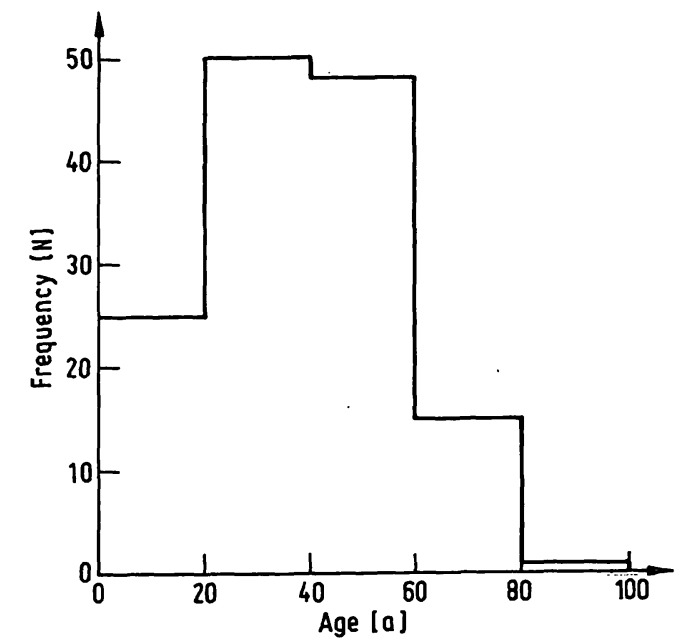

Fig. 1. Frequency distribution of all persons in relation to age. $\bar{x}=38$ years.

\section{Methods}

\section{Statistical method}

The F-test was used to compare the variances of the different groups. In case of equal variances, the Student's t-test was used to determine whether the groups were from the same or from different populations. In case of unequal variances the test of Welch was used instead of Student's t-test. A $95 \%$ level of significance was chosen for all the statistical tests.

Methods of analy sis

Glucose

Glucose was determined with the $o$-toluidine reaction without acetic acid (reagent Merck).

\section{Chloride}

Chloride was determined with a chlorocounter (Marius).

\section{Aspartate transaminase and lactate dehydrogenase}

Measurements of the activities of the enzymes aspartate transaminase and lactate dehydrogenase were made with the LKB 8600 Reaction Rate Analyzer with Kabi reagents. The method for aspartate transaminase is based on the rate at which oxaloacetate develops. This reaction is.coupled to the reaction catalyzed by the enzyme malate dehydrogenase. In this reaction NADH is oxidized to NAD and the rate of decrease in absorbance at $340 \mathrm{~nm}$ is measured.

In the determination of lactate dehydrogenase, the enzyme is allowed to catalyze the reaction pyruvate $+\mathrm{NADH}+\mathrm{H}^{+} \leftrightarrows$ lactate + NAD. The rate at which NADH is converted to NAD is then proportional to the amount of enzyme in the sample.

\section{Total protein}

For the determination of the total protein some of the samples were analysed by a direct spectrophotometric method after removal of interfering substances by gel filtration (Sephadex G 50) (5). In 1974 a less cumbersome method was applied:

this analysis is based on coprecipitation of protein and Ponceau-S dye by trichloroacetic acid, and spectrophotometric determination of the dye in alkaline solution af ter dissolution of the precipitate in dilute alkali (6).

\section{Protein fractions}

Concentration of CSF

Two techniques were used for the concentration of the CSF before electrophoresis: filtration under high pressure of nitrogen, (Ultra filters type SM $121 / 36$, Sartorius Membrane Filter GmbH
Göttingen) ( 30 samples) and an ultrafil tration system (Amicon D-15, Amicon, Oosterhout, Holland) (109 samples). We found no difference between the two techniques.

\section{Protein electrophoresis}

Up to 1972 electrophoresis was carried out on agar gel according to Wieme (7). Buffer: Veronal- $\mathrm{HCl} \mathrm{pH} 8.4$ ionic strength 0.05 , staining by Amido Black. The relative concentrations of the pre-albumin and the globulin fractions were determined with a scanner (Chromoscan), but this instrument did not allow the registration of the whole albumin fraction at the same time with total of all the globulin fractions and the pre-albumin. If the complete albumin curve was obtained, the sensitivity of the instrument was so decreased that the other fractions could not be properly scanned. After concentration of the sample, albumin was determined by the Radial Immuno Diffusion Technique (normal plates), and the concentration factor was established by the determination of the total protein in a 100 fold diluted sample of the concentrated CSF sample (method A). Since 1972 electrophoresis has been carried out on cellulose-acetate with the Boskamp mikrophore apparatus according to the instructions described in the manual, using Ponceau-S as the stain. The strips were scanned with a Vitatron TLD 100 scanner. This scanner allows the quantitation of both the albumin- and both the globulin fractions (Method P).

\section{Results}

\section{Precision of the analytical methods}

The day to day variation of the methods used, showed, with the help of a control sample, a precision which is comparable with those found in the literăture (tab. 1).

\section{Correlation between the different methods for total protein and the protein fractions}

The correlation between the two methods for the determination of total protein was excellent. When comparing the electrophoresis methods ( $\mathrm{A}$ and $\mathrm{P}$ ) lower values for albumin and higher values for pre-albumin and globulin fractions were obtained with method A (tab. 2).

Therefore the reference values of all protein fractions of the group patients with method $A(N=30)$ were compared with the reference values of the group patients determined with method $P(N=109)$ with the help of the F-test and the Student's test. Both groups belonged to the same population and no statistically significant differences could be detected.

\section{Shape of distribution curves}

The frequency-distribution curve was determined for all the items. With the test of d'Agostino, it is possible to determine if a distribution has a normal curve $(N)$ or a logarithmic normal curve (LN). See table 3 for the results.

For chloride we found a normal curve. For glucose both the criteria for normal and logarithmic normal were suited with a slightly better lognormal curve. The enzymes lactate dehydrogenase and aspartate transaminase had lognormal curves. Of the proteins, total protein, pre-albumin and albumin had normal curves, 
Tab. 1. The day to day precision of the analytical methods.

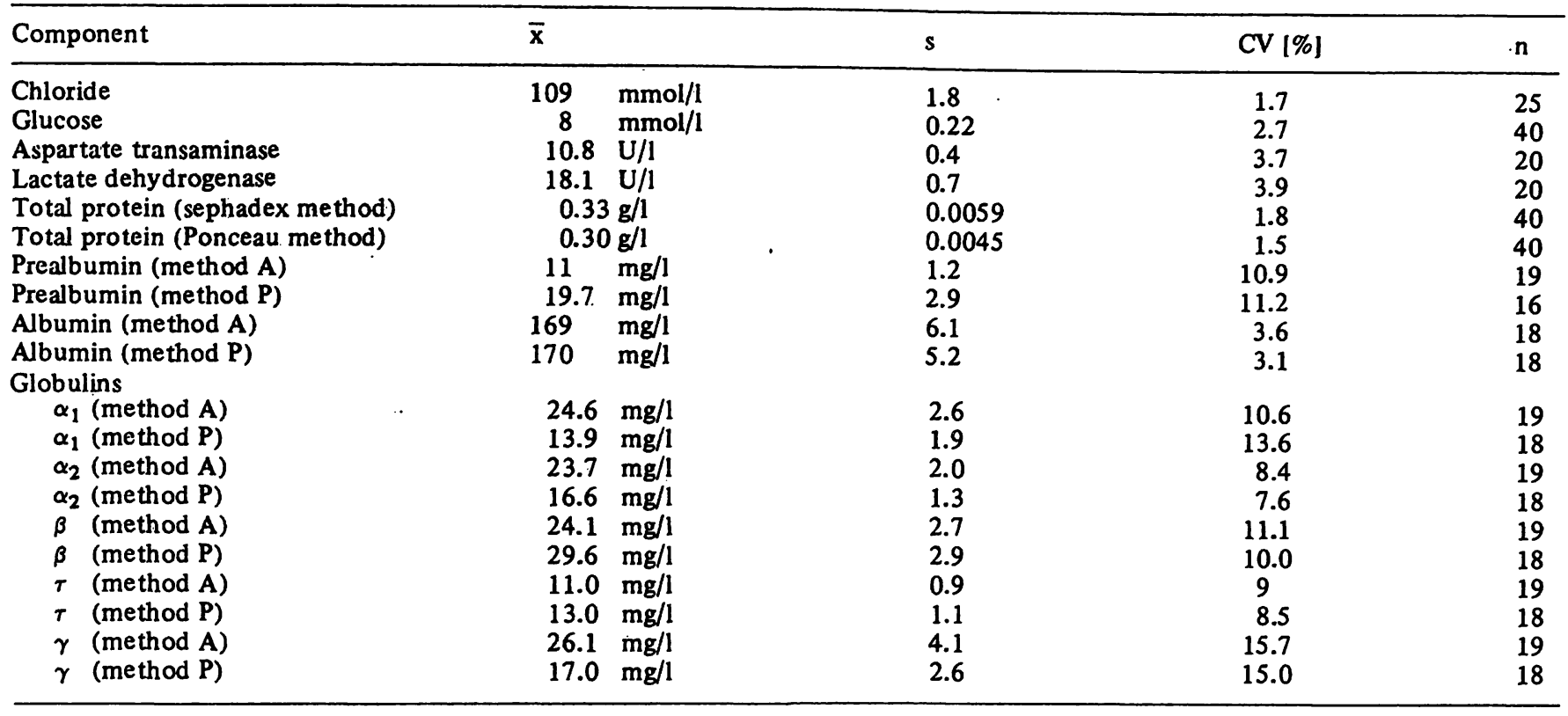

Tab. 2. Correlation data of the various techniques for total protein and protein fractions.

\begin{tabular}{|c|c|c|c|c|c|}
\hline Component & $\bar{x}$ & $\mathbf{n}$ & slope & $y$-intercept & $r$ \\
\hline $\begin{array}{l}\text { Total protein } \\
\text { Prealbumin } \\
\text { Albumin }\end{array}$ & $\begin{array}{cc}0.36 \mathrm{~g} / \mathrm{l} \\
17.7 \mathrm{mg} / 1 \\
446 & \mathrm{mg} / \mathrm{l}\end{array}$ & $\begin{array}{l}35 \\
20 \\
20\end{array}$ & $\begin{array}{l}0.99 \\
0.53 \\
1.02\end{array}$ & $\begin{array}{c}0.02 \\
7.4 \\
-19.8\end{array}$ & $\begin{array}{l}0.986 \\
0.812 \\
0.986\end{array}$ \\
\hline $\begin{array}{l}\text { Globulins } \\
\alpha_{1} \\
\alpha_{2} \\
\beta \\
\tau \\
\gamma\end{array}$ & $\begin{array}{ll}28.2 & \mathrm{mg} / 1 \\
32.1 & \mathrm{mg} / \mathrm{l} \\
43.4 & \mathrm{mg} / 1 \\
16.3 & \mathrm{mg} / \mathrm{l} \\
47.0 & \mathrm{mg} / \mathrm{l}\end{array}$ & $\begin{array}{l}20 \\
20 \\
20 \\
20 \\
20\end{array}$ & $\begin{array}{l}0.95 \\
0.84 \\
0.77 \\
0.72 \\
0.97\end{array}$ & $\begin{array}{r}0.6 \\
4.9 \\
10.7 \\
6.7 \\
8.6\end{array}$ & $\begin{array}{l}0.971 \\
0.951 \\
0.952 \\
0.815 \\
0.991\end{array}$ \\
\hline
\end{tabular}

Tab. 3. Reference values and type of distribution curves of the components, analyzed for all the samples $(\mathrm{N}=139)$. $N=$ Normal curve LN = Logarithmic Normal curve. (2) (3) (4) Values given in reference (2) (3) and (4).

\begin{tabular}{|c|c|c|c|c|c|}
\hline Component & $\overline{\mathbf{x}}$ & $\bar{x} \pm 2 s$ & & unit & $\begin{array}{l}\text { Type of } \\
\text { distribution }\end{array}$ \\
\hline Chloride & 125 & 119 & -132 & $\mathrm{mmol} / 1$ & $\mathbf{N}$ \\
\hline Glucose & 3.3 & 2.3 & -4.7 & $\mathrm{mmol} / \mathrm{l}$ & LN \\
\hline Aspartate transaminase & 5 & 2 & -13 & $\mathrm{U} / 1$ & LN \\
\hline Lactate dehydrogenase & 11 & 6 & -22 & $\mathrm{U} / \mathrm{l}$ & LN \\
\hline Total protein & 0.31 & $\begin{array}{l}0.14 \\
0.18 \\
0.17 \\
0.20\end{array}$ & $\begin{array}{ll}- & 0.49 \\
- & 0.41(2) \\
- & 0.54(3) \\
- & 0.47(4)\end{array}$ & $\mathrm{g} / \mathbf{1}$ & $\mathbf{N}$ \\
\hline Prealbumin & $\begin{array}{l}14 \\
19(3)\end{array}$ & 6 & -22 & $\mathrm{mg} / 1$ & $\mathbf{N}$ \\
\hline Albumin & $\begin{array}{l}200 \\
229(3)\end{array}$ & 70 & -330 & $\mathrm{mg} / \mathrm{l}$ & $\mathbf{N}$ \\
\hline$\alpha_{1}$-Globulin & $\begin{array}{l}17 \\
13(3)\end{array}$ & 7 & -39 & $\mathrm{mg} / \mathrm{l}$ & $\mathbf{L N}$ \\
\hline$\alpha_{2}$-Globulin & $\begin{array}{l}19 \\
18(3)\end{array}$ & 9 & -42 & $\mathrm{mg} / \mathrm{l}$ & LN \\
\hline B-Globulin & $\begin{array}{l}27 \\
31(3)\end{array}$ & 13 & -54 & $\mathrm{mg} / \mathrm{l}$ & LN \\
\hline$\tau$-Globulin & 22 (3) & 6 & -26 & $\mathrm{mg} / 1$ & LN \\
\hline$\gamma=$ Globulin & $\begin{array}{l}19 \\
30(3)\end{array}$ & 7 & -49 & $\mathrm{mg} / \mathrm{l}$ & $\mathbf{L N}$ \\
\hline
\end{tabular}

Normal ranges for serum: Aspartate transaminase $<13 \mathrm{U} / 1$, Lactate dehydrogenase $<200 \mathrm{U} / 1$ 
but all the globulin-fractions were logarithmic normal shaped.

\section{Reference values for all the patients $(N=139)$}

It has been customary to define the reference values as belonging to that portion of the entire range that includes $95 \%$ of the test data. In normal distributions this is the mean \pm 2 standard deviations. In a logarithmic normal distribution the curve became normal by transforming the values to the logarithm of the values. The results of the total number are grouped in table 3.

\section{Differences between the sexes}

For males $(\mathrm{N}=69)$ and for females $(\mathrm{N}=70)$ separately the reference values were determined as described for all the patients. In order to know whether males and females could be considered as the same population "the "F" test" and Student's " $t$ " test or Welch's test were applied. In the male population we found higher values for glucose, total protein, albumin and $\gamma$-globulin (tab. 4).

\section{Differences between age groups}

The possible influence of age was tested by comparing the age group $20-40$ years $(N=50)$ with the age group $>40$ years $(\mathrm{N}=55)$. Values of these two groups were compared as described under differences between the sexes. In the group $>40$ years slightly higher values for the $\gamma$-globulin fraction were found (tab. 5).

\section{Influence of age and sex on the components total protein and albumin}

For this purpose we devided the total number into four groups: males (20-40 years of age), males $(>40$ years of age), females (20-40 years of age), females $>40$ years of age). The total protein and albumin values were estimated and the comparison between groups was made as described for all the patients. For males significant higher values were found, but no influence of age could be detected (tab. 6).

Tab. 4. Reference values for males and females. Males: $N=69$, average age 35.9 ; females: $N=70$, average age 40.2. The last column shows whether the two ranges are indicative of the same or different populations.

\begin{tabular}{|c|c|c|c|c|c|c|c|c|}
\hline \multirow[t]{2}{*}{ Component } & \multicolumn{3}{|l|}{ Males } & \multicolumn{3}{|c|}{ Females } & \multirow[t]{2}{*}{ Unit } & \multirow{2}{*}{$\begin{array}{l}\text { Significant } \\
\text { difference }\end{array}$} \\
\hline & $\overline{\mathbf{x}}$ & $\bar{x} \pm 2 s$ & & $\overline{\mathbf{x}}$ & $\bar{x} \pm 2 s$ & & & \\
\hline Chloride & 126 & 119 & -132 & 125 & 119 & -131 & $\mathrm{mmol} / 1$ & No \\
\hline Glucose & 3.4 & 2.3 & -5.0 & 3.3 & 2.4 & $-\quad 4.4$ & $\mathrm{mmol} / \mathrm{l}$ & Yes \\
\hline Aspartate dehydrogenase & 5 & 2 & -13 & 5 & 2 & -13 & $\mathrm{U} / \mathrm{l}$ & No \\
\hline Lactate dehydrogenase & 11 & 6 & -22 & 12 & 6 & -22 & $\mathrm{U} / \mathrm{l}$ & No \\
\hline Total Protein & 0.33 & 0.15 & -0.51 & 0.29 & 0.13 & $-\quad 0.46$ & $g / 1$ & Yes \\
\hline Prealbumin & 15 & 6 & -24 & 14 & 7 & -22 & $\mathrm{mg} / \mathrm{l}$ & No \\
\hline Albumin & 210 & 100 & -350 & 190 & 120 & -300 & $\mathrm{mg} / \mathrm{l}$ & Yes \\
\hline$\alpha_{1}$-Globulin & 17 & 7 & $-\quad 39$ & 16 & 6 & $-\quad 38$ & $\mathrm{mg} / 1$ & No \\
\hline$\alpha_{2}$-Globulin & 20 & 9 & -44 & 19 & 10 & -39 & $\mathrm{mg} / \mathrm{l}$ & No \\
\hline$\beta$-Globulin & 27 & 13 & -56 & 26 & 14 & -51 & $\mathrm{mg} / \mathrm{l}$ & No \\
\hline$\tau$-Globulin & 13 & 5 & -28 & i1 & 6 & -23 & $\mathrm{mg} / \mathrm{l}$ & No \\
\hline$\gamma$-Globulin & 21 & 9 & -52 & 17 & 6 & -44 & $\mathrm{mg} / \mathrm{l}$ & Yes \\
\hline
\end{tabular}

Tab. 5. Influence of age was tested by comparing the group 20-40 years of age $(N=50)$ with the group $>40$ years of age $(N=55)$. The last column shows whether the two ranges are indicative of the same or different populations.

\begin{tabular}{|c|c|c|c|c|c|c|c|c|}
\hline \multirow[t]{2}{*}{ Component } & \multicolumn{3}{|c|}{ age $20-40$} & \multicolumn{3}{|c|}{ age $>40$} & \multirow[t]{2}{*}{ Unit } & \multirow{2}{*}{$\begin{array}{l}\text { Significant } \\
\text { difference }\end{array}$} \\
\hline & $\bar{x}$ & $\overline{\bar{x}} \pm 2 s$ & & $\overline{\mathbf{x}}$ & $\bar{x} \pm 2 s$ & & & \\
\hline Chloride & 126 & 120 & -132 & 126 & 120 & -132 & $\mathrm{mmol} / \mathrm{l}$ & No \\
\hline Glucose & 3.3 & 2.5 & $-\quad 4.6$ & 3.3 & 2.5 & $-\quad 4.6$ & $\mathrm{mmol} / \mathrm{l}$ & No \\
\hline Aspartate transaminase & 5 & 2 & -13 & 5 & 2 & -13 & $\mathrm{U} / 1$ & No \\
\hline Lactate dehydrogenase & 11 & 6 & -19 & 12 & 7 & -21 & $\mathrm{U} / \mathrm{l}$ & No \\
\hline Total protein & 0.32 & 0.24 & $-\quad 0.50$ & 0.33 & 0.18 & $-\quad 0.48$ & $g / 1$ & No \\
\hline Prealbumin & 15 & 4 & -25 & 15 & 7 & -21 & $\mathrm{mg} / \mathrm{l}$ & No \\
\hline Albumin & 210 & 70 & -340 & 200 & 90 & -320 & $\mathrm{mg} / \mathrm{l}$ & No \\
\hline$\alpha_{1}$-Globulin & 16 & 7 & -36 & 17 & 8 & -39 & $\mathrm{mg} / \mathrm{l}$ & No \\
\hline$\alpha_{2}$-Globulin & 19 & 9 & -40 & $21^{\circ}$ & 11 & -42 & $\mathrm{mg} / \mathrm{l}$ & No \\
\hline$\beta$-Globulin & 26 & 13 & -53 & 30 & 16 & -54 & $\mathrm{mg} / \mathrm{l}$ & No \\
\hline$\tau$-Globulin & 11 & 6 & -22 & 14 & 7 & -25 & $\mathrm{mg} / \mathrm{l}$. & No \\
\hline$\gamma$-Globulin & 17 & 7 & -43 & 21 & 4 & -54 & $\mathrm{mg} / \mathrm{l}$ & Yes \\
\hline
\end{tabular}


Tab. 6. Influence of age and sex for the components total protein and albumin. Significantly higher valucs were found for males in comparision with females. No influence of age could be detected.

\begin{tabular}{llllllrl}
\hline Groups & Number & \multicolumn{2}{l}{ Total protein } & Unit & \multicolumn{2}{c}{ Albumin } & \multirow{2}{*}{ Unit } \\
& $\mathrm{N}$ & $\overline{\mathbf{x}}$ & $\overline{\mathbf{x}} \pm 2 \mathrm{~s}$ & & $\overline{\mathbf{x}}$ & $\overline{\mathbf{x}} \pm 2 \mathrm{~s}$ & \\
\hline Males 20-40 & 27 & 0.33 & $0.13-0.53$ & $\mathrm{~g} / 1$ & 210 & $70-360$ & $\mathrm{mg} / 1$ \\
Males $>40$ & 28 & 0.36 & $0.14-0.48$ & $\mathrm{~g} / \mathrm{l}$ & 230 & $130-330$ & $\mathrm{mg} / \mathrm{l}$ \\
Females 20-40 & 23 & 0.30 & $0.15-0.45$ & $\mathrm{~g} / \mathrm{l}$ & 190 & $80-310$ & $\mathrm{~m} / \mathrm{l}$ \\
Females $>40$ & 36 & 0.30 & $0.15-0.45$ & $\mathrm{~g} / \mathrm{l}$ & 190 & $80-300$ & $\mathrm{mg} / \mathrm{l}$ \\
\hline
\end{tabular}

\section{Discussion}

In order to determine the reference values, we first had to estimate the type of frequency curve. The differences between the various techniques, i. e., electrophoresis techniques (method A and method P) and the two concentration techniques for the CSF samples, did not influence the results when the populations of both groups were compared by statistical tests (F-test and Student's test).

The results are in accordance with the experiments of Krause (8), who found that the ultrafiltration method gave lower albumin values and higher $\boldsymbol{\gamma}$-globulin values than filtration under high pressure, but the differences were small; he also found only small differences in the globulin fractions when comparing Amido-Black staining with the Ponceau-S staining.

We chose the normal curve for historical reasons, because many given normal ranges are based on the concept of the Gaussian curve. Secondly we tested the logarithmic normal curve, as this type is fitted for many biological distributions (9).

Other distributions such as Poisson, binomial etc. were not tested because for all items the curves were within the norms of either the normal distribution or the logarithmic normal distribution. As far as described the curves were similar to those found in the literature (4). The reference values that we found by using all the samples $(N=139)$ are comparable with the ranges found by other investigators $(2,4)$, but the globulin fractions showed higher upper limits as can be seen from the logarithmic shaped distribution.

The differences in values of total protein, albumin and $\gamma$-globulin between males and females are not great, but may be of clinical interest in cases of doubt.

No difference in total protein between males and females was found by Jung (2); slightly different, but statistically non-significant (Wilcoxon Test) values were found by Mertin et al (3), but higher values for albumin and $\gamma$-globulin in the serum of males have been found by several investigators $(10,11)$.

When testing the influence of age by comparing two age groups (20-40) and $>40$ years, no increase in the parameters could be detected, except for the $\gamma$-globulin fraction. Jung et al. found a slight increase of total protein with age (2).

In conclusion the results show that, using statistical methods, the frequency distribution of the enzymes and of the globulin fractions were logarithmic normal shaped; no differences were found for total protein with increasing age and significant differences were found between the sexes for total protein, albumin and $\gamma$-globulin.

\section{Acknowledgements}

The authors are indebted to Mr. P. Boon of the URC-Nijmegen for the organisation of the statistical part of the investigations, to Mr. J. Hart for carrying out the statistical analyses. Miss $A$. Dijkstra is thanked for her skilfully technical assistance in carrying out the liquor analyses.

\section{References}

1. Rieder, H. P., Jung, P. R. \& Burri, V. (1972), this J. 10, $379-384$

2. Jung; P. R., Rieder, H. P. \& Jeltsch, C. (1973), Klin. Wochenschr. S1, 810-816.

3. Mertin, J., Wisser, H. \& Doerr, P. (1971), this J. 9, 337-340.

4. Weisner, B., Schnedler, R. \& Bernharat, W. (1975), Nervenarzt 46, 532-538.

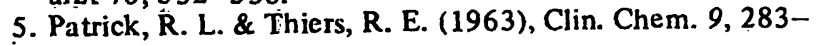
296.

6. Pesce, M. A. \& Strande, C. S. (1973), Clin. Chem. 19. 1265-1267.

7. Wieme, R. J. (1965), Agar Gel Electrophoresis, Elsevier, Amsterdam.

8. Krause, H. D., Wisser, H. \& Pirke, K. M. (1975), this J. 13, 79-84.

9. Martin, H. F. Gudzinourcz, B. J. \& Fanger, H. (1975), in: Normal values in clinical chemistry (chapter 3), Marcel Dekker Inc., New York.

10. Störiko, K. (1968), Blut 16, 200-208.

11. Stcinfeld, J. L. (1960), J. Lab. Clin. Med. 55, 904-911.

Ir. K. Brcebaart

Diaconessen $\mathrm{Hu}$ is

Lawick van Pabststraat 72

NL-6814 HB Arnhem 
. 